\title{
Value Constitutionalism in the European Union
}

\author{
Frank Schorkopf*
}

(Received 02 July 2020; accepted 08 July 2020)

\begin{abstract}
European constitutional thinking is still alive and is being shaped by the European Court of Justice into a value constitutionalism. Not only the Treaties, but also constitutional principles derived from EU law, are the common standard of review. Autonomy and constitutionality merge. In the light of this situation the Federal Constitutional Court's PPSP-judgment with its insistence on limitations of competences and on democratic self-determination appears outdated. However, for the time being, Member States agreed to cooperate in a treaty based political union and do not have a consensus on a "good order" in organized Europe. The Court should abstain from the temptation to operate with values because presumably it would not be able to achieve the substantiation and the creation of a value hierarchy with the necessary acceptance.
\end{abstract}

Keywords: Constitutionalism; European Union; Values; European Court of Justice; Federal Constitutional Court

\section{A. European Constitutionalism}

In 2007, it took the European Council just one sentence free from sentimentality to bid farewell to a dream of the founding years of European integration: "The constitutional concept, which consisted in repealing all existing Treaties and replacing them by a single text called 'Constitution,' is abandoned." The treaty on a constitution for Europe had failed two years before in negative referenda in France and the Netherlands, two of the states from the early beginnings of an organized Europe. What followed was a "reflection phase" which ended with the Berlin Declaration on the $50^{\text {th }}$ anniversary of the signing of the Rome Treaty. With this declaration the governments of the Member States agreed to continue the path of integration ${ }^{2}$ - the result of the negotiations of the constitutional convention was, with small modifications and abandoning the constitutional concept, carried over to the Lisbon Treaty. With the knowledge of subsequent integration events, we are now aware that European constitutionalism remains alive. ${ }^{3}$

${ }^{\star}$ Professor of Law, University of Göttingen, fschork@gwdg.de. I am grateful to Laura Hughes-Gerber, Leicester, for translation as well as Ronja Juckols, Friedrich Reichel and Ferdinand Weber for further support. German version: Wertekonstitutionalismus, 75 JURISTENZEITUNG (JZ) 477-485 (2020).

${ }^{1}$ Presidency Conclusions, Brussels European Council (June 21/22, 2007), 11177/07, Annex I, 15.

${ }^{2}$ The Declaration is available in Bulletin EU03-2007, point II.1; see Christian Tomuschat, La Déclaration de Berlin, in REvUE du Marché Commun et de L'union Européenne 283-285 (2007).

${ }^{3}$ Cf. Principles of European Constitutional Law (Armin v. Bogdandy \& Jürgen Bast eds., $2^{\text {nd }}$ ed. 2010); Verfassung Der Europäischen Union: Kommentar der Grundlagenbestimmungen (Christian Calliess \& Matthias Ruffert eds., 2006); Michael Longo, Constitutionalising Europe (2006); Mark Dawson \& Floris de Witte, From Balance to Conflict: A New Constitution for the EU, 22 EUR. L.J. 204, 204-224 (2016); Koen Lenaerts \& Jose A. Gutiérrez-Fons, The Constitutional Allocation of Powers and General Principles of EU Law, 47 CommON MKT. L. Rev. 1629, 1629-1669 (2010).

(C) The Author(s), 2020. Published by Cambridge University Press on behalf of the German Law Journal. This is an Open Access article, distributed under the terms of the Creative Commons Attribution-NonCommercial-NoDerivatives licence (http://creativecommons.org/ licenses/by-nc-nd/4.0/), which permits non-commercial re-use, distribution, and reproduction in any medium, provided the original work is unaltered and is properly cited. The written permission of Cambridge University Press must be obtained for commercial re-use or in order to create a derivative work. 
Initially, only few organs, committees, and fora-i.e. the European Parliament, the European Court of Justice and partly European legal scholarship cared about this fact because they had been striving towards the constitutionalism of Europe for decades. The formal upscaling of primary law as depicting legislation autonomous from the Member States' intentions, yet politically highly legitimated, hadn't worked on a European political level. Still, the Member States in the European Council, which decided to realize the later Treaty of Lisbon without the constitutional concept, could only manage to keep it out of the treaty amendment process. Immediately after the constitutional treaty's vanishing as political project, European constitutionalism was discredited due to the failure of the ambitious project not being attributed a substantial degree; ${ }^{4}$ today the idea has not endured. Recently, and due to the jurisprudence of the Court, it has reached a new stage of development which I refer to as a "constitutionalism of values." In the following, I will describe this constitutionalism of values from an integrationist historical perspective to clarify that the classic federal constitutional standpoint has been expanded to include a new ethos-related element. By doing so, I will attempt to justify the theory that the value-related constitutionalisation of the European Union not only suffers from a lack of legitimacy, but in addition and in its consequences will effect a barely appreciable transformation of the form of organized Europe.

\section{B. Conflicts of Interpretation between Delegationists and Constitutionalists}

The European Communities were conceptualized early-already in the Schuman Plan's negotiations-in a constitutional manner. Particularly in the German delegation, the viewpoint was adopted to think of the European Coal and Steel Community in constitutionally orientated concepts and terms. ${ }^{5}$ Advocates of the opposing viewpoint thought of the new collaboration in public international law terms, which meant that European Coal and Steel Community law was interpreted restrictively in favor of the Member States, limiting the competences of the High Authority. The "constitutionalists," however, wished to broadly interpret the treaty articles orientated around the objectives of the European Coal and Steel Community and through which the High Authority would have been granted more leeway. ${ }^{6}$

Detailed studies between lawyers pertaining to this intellectual conflict show that it is a generational conflict in which the "supranationalists" ${ }^{7}$ mostly belong to the younger (generation) and the "intergovernmentalists" to the older generation. ${ }^{8}$ The conflict in interpretation, differentiated and

\footnotetext{
${ }^{4}$ Matej Avbelj, Questioning EU Constitutionalisms, 9 German L.J. 1, 1 (2008).

${ }^{5}$ Hermann Mosler, Der Vertrag über die Europäische Gemeinschaft für Kohle und Stahl, 14 ZEITSCHRIFT FÜR AUSLÄNDISCHES ÖFFENTLICHES RECHT UND VÖLKERRECHT (ZAÖRV) 1, 36 (1951/52). Mosler was a member of the German negotiating delegation to the Schuman plan, for further information see FELIX LANGE, PRAXISORIENTIERUNG UND GEMEINSCHAFTSKONZEPTION 168-169, 176 (2017); Carl Friedrich Ophüls, Juristische Grundgedanken des Schumanplans, 4 NeUe JuRISTISCHE WochensChrift (NJW) 289, 289-291 (1951). Ophüls was also a member of the negotiating delegation, see Hans-Jürgen Schlochauer, Der übernationale Charakter der Europäischen Gemeinschaft für Kohle und Stahl, 6 JuristenZEitung (JZ) 289, 289-290 (1951). For further evidence, see also Anne Boerger \& Morten Rasmussen, Transforming European Law: The Establishment of Constitutional Discourse from 1950 to 1993, 10 EUR. CONST. L. REV. 199, 201-210 (2014).

${ }^{6}$ For the perspective of eye witnesses, see Heinrich Matthies, Die Bedeutung des Montanvertrages für das Gemeinschaftsrecht, in Commemorative Publication for Bodo Börner 233, 235 (Jürgen F. Baur et al. eds., 1992).

${ }^{7} J u l i e$ Bailleux, Comment l'Europe vint au droit, 60 Revue Française Science Politique (RFSP) 295, 316-317 (2010). In this context, see also Maurice Lagrange, Une réalité européenne: La Cour de Justice de la C.E.C.A., CAHIERS CHRÉTIENS De la Fonction Publique, 16, 19 (Apr. 28, 1955) (speaking for the supranationalists). For an early example from Germany, see Frank Schorkopf, Robert Krawielickis (1905-1966) Arbeit am Schmelztiegel eines allgemeinen europäischen Rechts, 67 JAHRBUCH DES ÖFFENTLICHEN ReCHTS (JöR) 553, 558-559 (2019).

${ }^{8}$ The debate reached its first peak during the two European congresses in Stres and Milan when, contrary to expectations, the public international lawyers initially prevailed. See Martin Thiele, Motor Der InTEgration 155-156, 352-352 (2019). On the first generation of European law specialists, specifically on the professional environment of the acting lawyers, see Harm Schepel \& Rein Wesseling, The Legal Community: Judges, Lawyers, Officials and Clerks in the Writing of Europe, 3 EUR. L. REV. 165, 165-166 (1997).
} 
varied, has dominated thought on the form of organized Europe ever since. It is the crucial reason behind the indecision of European citizens and politicians in regard of the European Union, which in turn has an impact upon the image of the Union itself, its form and its role both within Europe and internationally. ${ }^{9}$ The conflict revolves around the question as to which source European sovereignty nourishes itself from, in order to justify the autonomous design initially of the three European communities and today of the European Union. The intergovernmental or delegationist legal viewpoint regards the integrative Union as an organization based upon an international treaty and thus as a "club of cooperating states" and not as a federalist structure with a center and a periphery. The Union acts through its organs in the common interest of its Member States, which continue to bear-though jointly-sovereignty. ${ }^{10}$ The supranational or federal constitutional viewpoint is based upon the idea that the legitimate exercise of power of the integrative Union is derived not from the Member States but from their fused sovereignty rights and thus from a Community - and today a Union-interest. Both interpretations differ from one another inter alia in their justification of the democratic legitimacy of European authority. For the delegationists, the primary source lies in the Member States, while the constitutionalists consider the integrative Union and its connection to the Union's citizens or even to supranational justice to be the primary source.

In the negotiations of the Paris and Rome Treaties, the delegationist legal viewpoint in principle prevailed and substantiated itself accordingly in the infrastructural architecture. The principle of conferral (Art. 5 (2) TEU), according to which the Union must be conferred a competence by the Member States, is its most important manifestation. Although the delegationist legal interpretation still is the prevailing view amongst governments and constitutional courts, it has not completely repressed the rival federal constitutionalist viewpoint. The delegationists had to compromise from the beginning on. One compromise consisted of a European Parliament being created — initially onlyas a European parliamentary assembly ${ }^{11}$ — complemented by the monopoly right of initiative of the Commission. The constitutionalists in principle deferred the issue to the future and hoped for the European Communities to develop in a dynamic way. Still, the German Federal Government presented their act of ratification to the EEC and EAEC treaty inter alia using the expression: "The treaty calls into existence a European entity of a constitutional kind." ${ }^{2}$

\section{The 1970 s as a Key Decade}

Though initially scarcely noted, the key decisions of the European Court of Justice in the cases of Costa/ENEL and Van Gend en Loos (1963/1964) acted as a turning point. ${ }^{13}$

\footnotetext{
${ }^{9}$ Christoph Möllers, Pouvoir Constituant - Constitution - Constitutionalism, in PrINCIPLES OF EUROPEAN CONSTITUTIONAL LAW 169, 170 (Armin v. Bogdandy \& Jürgen Bast eds., $2^{\text {nd }}$ ed. 2010); Frank Schorkopf, Constitutionalization or a Constitution for the European Union?, in The Emerging Constitutional Law of the European Union 1, 9-10 (Eszter Bodnar et al. eds., 2003).

${ }^{10} \mathrm{Cf}$. Martin Nettesheim, “Gegründet auf Werten ... ": Das Narrativ der Wertegemeinschaft und der Sanktionsmechanismus des Art. 7 EUV, in Die Neuerfindung Europas 91, 102 (Claudio Franzius, Franz C. Mayer \& Jürgen Neyer eds., 2019). In this regard, the "club" term has been adopted by Armin v. Bogdandy \& Laura Hering, In the name of the European club of liberal democracies, MPIL RESEARCH PAPER SeRIES No. 2020/1, and the evidence provided in Explanatory Note 30 et seq.

${ }^{11}$ The parliamentary assembly was only formally renamed to "European Parliament" upon the EEA coming into force on 1. July 1987; the assembly gave itself this name in 1962 and acted thereunder.

${ }^{12}$ Deutscher Bundestag: Drucksachen und Protokolle [BT] 2/3340 108 (Ger.). The five other states did not make use of constitutional semantics. This quote has been translated from the original in German - N.B. this is not an official translation.

${ }^{13}$ ECJ, Case C-26/62, NV Algemene Transport- en Expeditie Onderneming van Gend \& Loos v. Neth. Inland Rev. Admin., ECLI:EU:C:1963:1, Judgment of Feb. 5, 1963 at 3, para, 24; ECJ, Case C-6/64, Costa v. E.N.E.L., ECLI:EU:C:1964:66. Judgment of July 15 at 1141, 1269. For a reconstruction of the background to the judgment in the case of van Gend en Loos see Morten Rasmussen, Revolutionizing European Law: A History of the Van Gen den Loos Judgment, 12 INT'L J. Const. L. 136 (2014). The Court itself strives towards historicising the judgment, see the articles contained in COURT OF JUSTICE OF THE EUROPEAN UnION, 50 ${ }^{\mathrm{EME}}$ ANNIVERSAIRE DE L'ARRÊT VAN GEND EN LOOS, 1963-2013 (2013). On the background to the Costa/ENEL
} 
Through the decisions, the Court expressed European law's claim to autonomy and relaxed the dependence of its legitimacy on national parliamentarianism. Autonomy is defined as self-sufficiency, i.e. the bearer of autonomy provides itself with its own rules and shields itself against those outside of the sphere of autonomy. In relation to European Union law, this represents an interpretation detached from international legal and Member State bias, which to a great extent decouples European Union law from external influences, in particular from purposes specific to Member States. The history of European law has by now mapped out that, in particular, the case of van Gend en Loos was linked by the Commission to constitutional thought, although such semantics cannot be found in either decision. ${ }^{14}$ Art. 138 (3) EEC Treaty, providing a legal basis for a unified European electoral process, was a second reference point for the constitutionalists. The norm implies the full parliamentarisation of the Community ${ }^{15}$ and therewith conveys the direct democratic legitimization of a European citizenship. Though this unified right to vote has not materialized to the present day, the direct election to the European Parliament, mentioned in the aforementioned article, was achieved through modification of the Direct Elections Act in 1976. ${ }^{16}$ By now, the European Parliament has evolved as the political power of the Union, which is institutionally close to equal to the Council and according to its own conception as a place of genuine Union interest, it is even superior thereto. ${ }^{17}$ At the end of the 1960s, the question of the constitutional legitimacy of European public power emerged alongside democratic legitimacy. The issue of fundamental rights protection like one of the broader "treaty conditions" was outsourced to the Council of Europe and the European Human Rights Convention it administered until then. ${ }^{18}$ In the course of the second discovery of human rights at the beginning of the $1970 \mathrm{~s}^{19}$ as well as by way of the Solange impulse from the German Federal Constitutional Court, the European Court of Justice discovered the current protection of fundamental rights in the form of the general principles of community law. ${ }^{20}$ The 1970 s are likely the key decade for value constitutionalism. The main focus no longer lay in anti-communism and the peace mission, although it was rhetorically dominant in integration but-put into the wider institutional context-had only a relative significance. The motive of proclaiming common values as the raison d'être of European integration emerged alongside. ${ }^{21}$ This newer motive manifested itself in a particularly clear way in the document on European identity from $1973 .{ }^{22}$ The desire of the nine states is explicitly formulated as "the principles of representative democracy, of the rule of law, of social justice - which is the ultimate goal of economic progress - and of respect for human rights. All of

case, see Amedeo Arena, From an Unpaid Electricity Bill to the Primacy of EU Law: Gian Galeazzo Stendardi and the Making of Costa v. ENEL, 30 EUR. J. INT'L L. 1017 (2019).

${ }^{14}$ Anne Borger-de Smedt, At the Cradle of Legal Scholarship on the European Union: The Life and Early Work of Eric Stein, 62 Amer. J. Comp. L. 859, 885-886 (2014). However, such formulations are to be found in the opinion of the Advocate General, Maurice Lagrange, in the case of Costa/ENEL, see Costa, Case C-6/64 at 600 ("[...] the constitutional relations between the European Economic Community and its member states [... ]"; "The Treaty of Rome has, in a sense, the character of a genuine constitution, the constitution of the Community [... .").

${ }^{15}$ See Treaty on the Functioning of the European Union art. 223 (1), Mar. 25, 1957 [hereinafter TFEU]; Enrico Peuker, Das Wahlrecht zum Europäischen Parlament als Achillesferse der europäischen Demokratie, 11 ZEITSCHRIFT FÜR EUROPARECHTLICHE STUDIEN 453, 453-454 (2008).

${ }^{16}$ Act concerning the election of the members of the European Parliament by direct universal suffrage, Council Directive 278/5, 1976 O.J. (L 278) 5-11; Juliet Lodge, The Significance of Direct Elections for the European Parliament's Role in the European Community and the Drafting of a Common Electoral Law, 19 COMMON MARKET L. Rev. 195 (1979).

${ }^{17}$ On the role of the Parliament, see Richard Corbett, The European Parliament's Role in Closer EU InTEgration (1998); Berthold Rittberger, Building Europe's Parliament 73-74 (2005).

${ }^{18}$ The Community was nevertheless concerning itself with questions of fundamental rights in the applications for membership of Spain and Greece, in which the Council and the Member States adopted a pragmatic stance, whilst the European Parliament supported a value orientated stance, $c f$. Kiran Klaus Patel, Project Europe 146-175 (2020).

${ }^{19}$ See Jan Eckel, Die Ambivalenz Des Guten 343-434 (2 $2^{\text {nd }}$ ed. 2015); Samuel Moyn, The Last Utopia (2010).

${ }^{20}$ See Frank Schorkopf, Der EuropäISChe Weg 132 (3rd ed. 2020).

${ }^{21}$ See PATEL, supra note 18.

${ }^{22}$ Declaration on European Identity, 12 Bulletin of THE Eur. COMM. 118, 131 (1973). 
these are fundamental elements of the European Identity." Three years earlier in the Davignon report, the six Member States of which the European Communities existed back then had already professed that "a united Europe should be based on a common heritage of respect for the liberty and rights of man and bring together democratic States with freely elected parliaments." A joint declaration of the organs, though not legally binding, to be bound by the fundamental rights of the community followed. ${ }^{23}$ European thought on fundamental rights led to the negotiation of the Charter of Fundamental Rights at the end of the 1990s after accession to the European Convention on Human Rights, as preferred by the EU's organs, had been declared contrary to EU law for the first time owing to the lack of primary law authorization for such an accession. ${ }^{24}$ This Charter of Fundamental Rights was (and is) aligned in its teleology towards the value system. The first three recitals of the preamble address the shared values of the Union and of the peoples of Europe, of which human dignity, freedom, equality and solidarity are explicitly named. ${ }^{25}$ Constitutional European thought gained greater publicity in the 1980s. The European Parliament, which regards itself as a "constitution developing" assembly since the entry into force of the Direct Election Act, brought forward a draft version of a treaty pertaining to the establishment of the European Union in 1984. The draft became known as the Spinelli draft ${ }^{26}$ and is regarded as a draft constitution. It initially led only to the Single European Act, ${ }^{27}$ which was viewed as technical and labelled as such, the first substantial amending treaty since the Treaty of Rome. Certainly not coincidentally but rather in the context of the Spinelli draft, in 1986 the European Court of Justice described the EEC Treaty using the wording "constitutional charter of the community", with which it established a much-cited and identity-building point of reference for constitutionalists. ${ }^{28}$ Constitutional thought on European integration moved closer to the current perspective by way of the aforementioned constitutional treaty, which incorporated the Fundamental Rights Charter and explicitly bound the Union and the Member States to uphold values.

\section{The New Line of Jurisprudence of the ECJ}

One can understand the five decades before the constitutional treaty collectively as a process in which three strands of development evolved one after the other: first, constitutional thinking, then thought on fundamental rights and finally value-orientated thought. The latter overlaps with fundamental rights to the extent that fundamental rights substantiate European values. These three strands of development have integrated into one in the present, for which I propose the term "value constitutionalism". How did it come to this and what does it mean? The calibration point of recent events was the Court's legal opinion of 2014 on accession to the ECHR. The leading argument for the Court in determining the incompatibility of the accession agreement with EU law, negotiated with the European Council, was the "new legal order" created by the Treaty of Rome and which distinguishes itself through "its own constitutional framework. ${ }^{29}$ The significance of the opinion lay in its timing and the explicit reference to constitutional

\footnotetext{
${ }^{23}$ Council \& Commission Joint Declaration 103/12, 1977 O.J. (C 103) 1 (EC). In this regard, see Meinhard Hilf, Die gemeinsame Grundrechtserklärung des Europäischen Parlaments, des Rates und der Kommission vom 5.4.1977, 4 EUROPÄISCHE GRUNDRECHTE-ZEITSCHRIFT (EUGRZ) 158 (1977).

${ }^{24}$ ECJ, Opinion 2/94, ECLI:EU:C:1996:140, Opinon of Mar. 28, 1996.

${ }^{25}$ Charter of Fundamental Rights of the European Union, Dec. 7, 2000, 2000 O.J. (C 364) 8 (EU) [hereinafter CFREU].

${ }^{26}$ Draft Treaty Establishing the European Union, 14 February 1984, 1984 O.J. (C 77) 33 [hereinafter Spinelli Draft].

${ }^{27}$ On the choice of name, see Luuk Van Middelaar, The Passage to Europe 105-111 (2013).

${ }^{28}$ ECJ, Case C-294/83, Parti écologiste "Les Verts" v. European Parliament, ECLI:EU:C:1986:16, para. 23 [hereinafter Les Verts].

${ }^{29}$ ECJ (Plenum), Case Opinion 2/13, ECLI:EU:C:2014:2454, para. 157, Opinion of Dec. 18, 2014. On the approaches already expressed in the opinion on the European patent court, see also ECJ (Plenum), Case Opinion 1/09, ECLI:EU:C:2011:123, para. 66, Opinion of Mar. 8, 2011, however at this point without constitutional phrasing.
} 
semantics, with both of the internal acts of the establishment of the supranational community of $1963 / 1964 .^{30}$ It was an unexpected thunderbolt that after years of negotiations, the EU again would be unable to accede to the European Convention on Human Rights, ${ }^{31}$ the common European catalogue of human rights, despite a primary law mandate and conformant political will. ${ }^{32}$ Particularly in the context of a cross-section in European legal history, the breakaway movement with which the ECJ positioned the EU as a community of values, stands out, also in distinguishing it from the Council of Europe, which for decades fulfilled the function of a European forum of values. The Court also desires to be a court of fundamental rights, alongside national constitutional courts and the European Court of Human Rights, which effectively protects EU citizens. ${ }^{33}$ It seems as though the Court wishes to safeguard the EU from becoming unitary through the human rights jurisprudence of the ECHR - if it would not be blatantly impossible, one could gain the impression that the Court is conducting itself like a national constitutional court, concerned as to its constitutional identity. ${ }^{34}$ The Court has used this constitutional terminology in this context ever since. In 2018 in the course of its judgment in the case of Portuguese judges, ${ }^{35}$ the Court took a momentous step theoretically and indeed dogmatically, as depicted by the follow-up jurisprudence in the likewise highly political cases of Achmea, Wightman, CETA und Commission/Poland. The line of jurisprudence already outlined infers the conclusion that the European Union has entered a new constitutional phase of self-preservation. This conclusion can be inferred because the Court derives the authority to review the judicial structures in the Member States from its allocation of functions under primary law (Art. 19 TEU). The Member States are obliged to establish "remedies sufficient to ensure effective legal protection in the fields covered by Union law." The Court regards this obligation as a substantiation of the common value of the rule of law (Art. 2 (1) TEU). In the treaty article, the general principle of effective judicial protection of rights under Union law is also reflected as it ensues from the common constitutional traditions of the Member States and from the human rights convention and as codified in Art. 47 Charter of Fundamental Rights. The dogmatic clamp between the EU legal system and the legal system of the Member States results from the principle of loyal cooperation, which obliges the Member States to ensure the application and preservation, of

\footnotetext{
${ }^{30}$ Frank Schorkopf, Bundesverfassungsgericht und Europäischer Gerichtshof, in VERFASSUNGSGERICHTSBARKEIT IN DER BONNER Republik 427, 434-442 (Florian Meinel ed., 2019).

${ }^{31}$ The European Commission has announced they will be undertaking a new attempt to accede to the ECHR under the guiding principle of the rule of law, see EUR. PARL. Doc. (COM 343) 7 (2019), which the Council accepted on October 7, 2019. In accepting additional principles for the mandate of negotiations, see Justice \& Home Affairs Report on the Outcome of the Council Meeting, Doc. Nr. 12837/19, 11. On the status of the debate, see Johan Callewaert, Considerations on the Absence of EU Accession to the ECHR and its Consequences, 55 COMMON MARKeT L. Rev. 1685 (2018); Martin Kuijer, The Challenging Relationship between the European Convention on Human Rights and the EU Legal Order: Consequences of a Delayed Accession, 22 InT'L J. Human Rights 1 (2018).

${ }^{32} \mathrm{TFEU}$ at art. 6 (2). This legal basis was established following Opinion 2/94 specifically pertaining to the "implementation" of the obstacles to accession, the ECJ had queried, $c f$. Opinion 2/94 at para. 26.

${ }^{33}$ In this respect, there is a parallel to the guiding principle l'Europe qui protège, which was introduced into the European debate by the French President, see L'Europe qui protège : "Cela ne se fera jamais." Vraiment?, ELYsEEs, https://www.elysee.fr/ emmanuel-macron/2019/03/05/inauguration-du-college-du-renseignement-en-europe. In this regard, cf. Marc Leonard, l'Europe qui protège: Penser l'Union Européenne à venir, European Council on Foreign Relations, August 2017, http:// www.ecsf.eu.

${ }^{34}$ Koen Lenaerts, Les fondements consitutitionnels de l'Union européenne dans leur rapport avec le droit international, in Liber AMORICUm VAssilios Skouris 367, 379 (Antonio Tizzano et al. eds., 2015) ("une identité constitutionnelle" under which the author includes primacy of application, direct effect, the principle of loyal cooperation and the general principles of law including fundamental rights.). For national perspectives, see CONSTITUTIONAL IDENTITY IN A EUROPE OF MULTILEVEL Constitutionalism (Christian Calliess \& Gerhard van der Schyff eds., 2020). On the problems with substantiating national constitutional identity in the context of TEU Art. 4 (2), see Marek Safian, Les dilemmes de l'application de standards plus élevés, in Liber Amoricum Vassilios Skouris 545, (Antonio Tizzano et al. eds., 2015).

${ }^{35}$ ECJ, Case C-64/16, Associação Sindical dos Juízes Portugueses v. Tribunal de Contas, ECLI:EU:C:2018:117, Judgment of Feb. 27, 2018.
} 
EU law in their territory. ${ }^{36}$ In other words, the Court, through its judgment, transformed the value of "the rule of law" into a legally subsumable and enforceable norm, which has become a benchmark for the structures and activity of the Member States' judiciaries. ${ }^{37}$ In the application and refinement of these legal issues, in the case of Commission/Poland, in dealing with the reduction of the retirement age of judges in office in the highest court and in the Presidential competency, the Grand Chamber regarded extending the active service of these judges beyond the newly established retirement age at one's own discretion as a breach of Art. 19 (1) TEU in connection with Art. 47 Charter of Fundamental Rights. ${ }^{38}$ In doing so, the Court drew upon the very substance (Art. 52 (1) Charter of Fundamental Rights) of Art. 47 (2) Charter of Fundamental Rights. ${ }^{39}$

Through Art. 19 and Art. 2 TEU, the Court construed an alternative approach to apply the fundamental rights of the Union without recourse to Art. 51 (1) Charter of Fundamental Rights. This step is new but certainly has an older point of reference, namely the genuine enjoyment of the substance of the rights conferred by virtue of a status, namely of EU citizenship (core concept) ${ }^{40}$ In earlier jurisprudence, the Court extended the scope of EU law, from which the scope of application of the Charter of Fundamental Rights ensued as a quasi-spin-off. Art. 51 (1) Charter of Fundamental Rights, in its preservation of Member State competence in paragraph 2 and Art. 6 (1) 2 TEU, is meaningless in this respect. ${ }^{41}$ The President of the Court, Koen Lenaerts, and his ECJ colleague, José Gutiérrez-Fons, clearly articulated this ancillary connection in an article on EU citizenship: "As we have explained elsewhere, the Charter is the 'shadow' of EU law. Just as an object defines the contours of its shadow, the scope of EU law determines that of the Charter." ${ }^{2}$ The core concept has not been transferred to the Union's values by the more recent jurisprudence. The idea of an inventory of supra positive Union rights epitomizing European justice however continues to exist. Building on value constitutionalism, it would be conceivable to derive the core essence of EU citizens' rights in future from Art. 19 in connection with the principle of freedom (Art. 2 TEU) and Art. 20 TFEU, as well as the core essence of Art. 45 (1) Charter of Fundamental Rights. ${ }^{43}$ As the Court established in a further judgment, EU citizenship belongs, alongside the ever closer Union and the values, to the fundamental principles of the EU. ${ }^{44}$ For this highly positive inventory of EU rights, which substantiate values, the Court invokes the unwritten EU constitutional law, in which the principle of judicial protection arising from EU law is declared a general principle of EU law (Art. 6 (3) TEU) for the individual. In a - for the European Union - challenging escalation of rule of law based institutions in Member States, the

\footnotetext{
${ }^{36} \mathrm{Id}$. at para. 30 (referencing Case Opinion $2 / 13$ at para. 168 , and explicitly the reference to TEU art. 4 (3)). Case Opinion $1 /$ 09 at para. 68.

${ }^{37}$ On this note, a literature inspired reaction to rule of law deficiencies in numerous Member States has commenced, Laurent Pech \& Sébastien Platon, Court of Justice Judicial Independence Under Threat: The Court of Justice to the Rescue in the ASJP case, 55 Common MARKET L. REv. 1827, 1836, 1848 (2018).

${ }^{38}$ ECJ, Case C-619/18, Comission v. Poland, ECLI:EU:C:2019:531, Judgment of July 11, 2019.

${ }^{39}$ Poland, Case C-619/18 at paras. 41, 50, 54, 57; ECJ, Case C-192/18, Comission v. Poland, ECLI:EU:C:2019:924, Judgment of Nov. 5, 2019 at paras. 101, 105. Cf. Armin v. Bogdandy \& Luke Dimitrios Spieker, Countering the Judicial Silencing of Critics: Article 2 TEU Values, Reverse Solange, and the Responsibilities of National Judges, 15 EUR. CONST. L. REV. 391, 421 (2019).

${ }^{40}$ ECJ, Case C-256/11, Dereci et al. v. Bundesministerium für Inneres, ECLI:EU:C:2011:734, Judgment of Nov. 15, 2011 at para 64. See Koen Lenaerts, The Court's Outer and Inner Selves: Exploring the External and Internal Legitimacy of the European Court of Justice, in Judging Europe's Judges 13, 45 (Maurice Adams et al. eds., 2015); Christina NeIER, Der KeRnBESTANDSSCHUtZ DER UnionsbÜRgERSCHAFt 220, 242 (2019).

${ }^{41}$ On the meaninglessness of CFREU Art. 51 (1), see ECJ, Case C-221/17, Tjebbes et al. v. Minister van Buitenlandse Zaken, ECLI:EU:C:2019:189, Judgment of Mar. 12, 2019 at para. 45; ECJ, Case C-133/15, Chavez-Vilchez et al. v. Raad van bestuur van de Sociale verzekeringsbank et al., ECLI:EU:C:2017:354, Judgment of May 10, 2017 at para. 70; ECJ, Case C-304/14, Home Department v. CS, ECLI:EU:C:2016:674, Judgment of Sept. 13, 2016 at para. 36; ECJ, Case C-165/14, Rendón Marín v. Administración del Estado, ECLI:EU:C:2016:675, Judgment of Sept. 13, 2016 at paras. 66, 81.

${ }^{42}$ Koen Lenaerts \& José A. Gutiérrez-Fons, Epilogue on EU-Citizenship: Hopes and Fears, in EU CITIZENSHIP AND FEDERALISM 751, 772 (Dimitry Kochenov ed., 2017).

${ }^{43}$ Cf. Christoph Möllers \& Linda Schneider, Demokratiesicherung in der EuropÄischen Union 105 (2018).

${ }^{44}$ ECJ, C-621/18, Wightman et al. v. Secretary of State, ECLI:EU:C:2018:999, Judgment of Dec. 10, 2018 at paras 61-64.
} 
Court reached for the constitutional argument in order to assert itself and the EU legal system. ${ }^{45}$ Ultimately, the Court merged constitutional thinking with the autonomy of EU law in a further key decision. Opinion 1/17 on the Trade and Investment Treaty between the EU and Canada (CETA) reads word for word:

"That autonomy accordingly resides in the fact that the Union possesses a constitutional framework that is unique to it. That framework encompasses the founding values set out in Article 2 TEU, which states that the Union 'is founded on the values of respect for human dignity, freedom, democracy, equality, the rule of law, and respect for human rights', the general principles of EU law, the provisions of the Charter, and the provisions of the EU and FEU Treaties, which include, inter alia, rules on the conferral and division of powers, rules governing how the EU institutions and its judicial system are to operate, and fundamental rules in specific areas, structured in such a way as to contribute to the implementation of the process of integration described in the second paragraph of Article 1 TEU (see, to that effect, Opinion 2/13 (Accession of the Union to the ECHR) of 18 December 2014, EU: C:2014:2454, paragraph 158)."46

The outlined reference to the "implementation of the process of integration described in the second paragraph of Article 1 TEU" means the ever closer Union, i.e. constitutionalism is serving the object of integration, which to date has been described as a process. The consequences of the Union's constitutional thinking are particularly apparent in Opinion 1/17. I refer to the part of the reasoning, in which the Court declares the CETA agreement to be incompatible with EU law because the agreement makes it impossible for EU organs to function in accordance with the constitutional framework of the EU. It is not only the treaties but also the constitutional principles derived from them which constitute the standard of review. Autonomy and constitutionality become one.

\section{E. Critique}

The Court falls back on the values clause in Art. 2 TEU and argues offensively using the constitutional principles of EU Law for a significant objective: the protection of the rule of law in the European Union and in the Member States. If Member States deviate from EU law and fail to uphold their obligations, it is likely that the Court relies not only on political solutions but sees the possibility of parallel legal approaches. This method allows it to bring disturbing issues in individual Member States before the Court. However, European law has now experienced that the Court proceeds tactically proficiently and undertakes dogmatic innovations, which as a consequence do not give Member States cause for complaint and which therefore render political reception easier. With a some distance from the individual decisions, it stands out that the Court as a consequence deserves approval that it is making use of a constitutional language in an increasing manner, interpreting European Union law not only from its autonomy but regarding its autonomy as supported by a change resistant—value orientated-substance. Art. 2 TEU could thus become an eternity clause in community law. ${ }^{47}$ Autonomy is becoming self-governance

\footnotetext{
${ }^{45}$ Koen Lenaerts, New Horizons for the Rule of Law Within the EU, 21 GERMAN L.J. 29 (2020) (“EU Law as Gatekeepers' Keeper").

${ }^{46}$ ECJ, Opinion 1/17, ECLI:EU:C:2019:341, Apr. 30, 2019, para. 110.

${ }^{47}$ The failure to take account of CFREU art. 51 (1) would in itself have provoked opposition in Karlsruhe, see Peter Michael Huber \& Andreas Paulus, Cooperation of Constitutional Courts in Europe, in CourTs AND Comparative LAW 281, 296 (Mads Andenas \& Duncan Fairgrieve eds., 2015) ("This is also true of the Court of Justice of the European Union as the guardian of the EU treaties (second sentence of TEU art. 19, sec. 1). However, this court adjudicates only within the area of application of EU law, and in the area of fundamental rights when implementing the law of the EU (Art. 51 sec. 1 CFREU)."); furthermore in the new jurisprudence of the First Senate on the "right to be forgotten" CFREU art. 51 is ascribed a competence preserving meaning in the fundamental federal relationship between the EU and the Member States. Cf. Bundesverfassungsgericht
} 
and could become the core of European sovereignty. ${ }^{48}$ The values clause in Art. 2 TEU makes the EU-as a legal subject-special insofar as even structural changes in the Member States adopted in the context of Parliamentary democracy can be addressed as issues of EU law. ${ }^{49}$ Against the backdrop of the relationship between Member States and the EU, the insistence on limitations of competences in the allocation of power is no longer compatible and appears outdated. Certainly, this is a question of perspective and therefore it does not come as a surprise that Germany's Federal Constitutional Court in its PPSP-judgment ${ }^{50}$ interpreted Art. 5 (1) TEU as guarantee of Member States' democratic self-determination. The EU clearly distinguishes itself from the Council of Europe, which most recently has had to act diplomatically towards Member States, which have raised doubts as to whether they still accept the "principle of the primacy of law" and the commitment to uphold human rights (Art. 3 Statute of the Council of Europe). ${ }^{51}$ With a view to these concessions and as ECtHR also asserts the claim to defend a "consistent social model" 52 for the European continent the EU conceive the idea to keep some equidistance.

The significance of the values clause becomes clearer from a different perspective, namely in the Opinion pertaining to the case of Egenberger. This preliminary ruling procedure originating in Germany dealt with the compatibility of a denominational tender for a position at a deaconry with anti-discrimination Directive 2000/78/EC. ${ }^{53}$ In the Opinion, Advocate General Tanchey in principle deals with a classification of Art. 17 TFEU, partially understood as a negative competence "church article" of primary law, which builds a bridge to integration models. ${ }^{54}$ According to the Advocate General, the treaty article is "not a meta-principle of constitutional law." As a typical example of such meta-principles, he names the sanction proceedings (Art. 7 TEU), the antidiscrimination cross-section clause (Art. 10 TFEU) and, from the fundamental rights, the specific prohibitions of discrimination (Art. 21 CFREU) and the guarantee of access to justice (Art. 47 CFREU) ${ }^{55}$ In the course of the reference to meta-principles, it becomes clear that the Advocate General obviously considers an internal division of primary EU Law, understood as "constitutional law." There is ordinary law and there are qualified meta-principles, the statements which denote that what is unavailable cannot be derogated from and is to be implemented as a matter of priority. ${ }^{56}$ The meta-principles are treated as a kind of peremptory EU law, its roots can

[BVerfG] [Federal Constitutional Court] Case No. 1 BvR 16/13, paras. 43, 53 (Nov. 6, 2019), http://www.bverfg.de/e/ rs20191106_1bvr001613.html.

${ }^{48}$ ANDrEas Bergmann, Zur SOUVERÄNITÄTSKONZEPTION DES EUROPÄISCHEN GERICHTSHOFs 251 (2018). On the possible transformation from autonomy to sovereignty not compensating for the erosion of sovereignty generally diagnosed, for more detail see Ferdinand Weber, Überstaatlichkeit als Kontinuität und Identitätszumutung, 66 Jahrbuch des Öffentlichen Rechts (JöR) 237, 273 (2018).

${ }^{49}$ In evaluating, it is to be kept in mind that the Member States have indeed introduced a sanction procedure for violations of values (Art. 7 TFEU), however, by way of the far-reaching jurisdiction limitation in TFEU art. 269, it was desired that the material operationalization of values by the ECJ be precluded.

${ }^{50}$ Bundesverfassungsgericht [BVerfG] [Federal Constitutional Court] Case No. 2 BvR 859/15 et al., paras. 110, 127, 131 (May 5, 2020), http://www.bverfg.de/e/rs20200505_2bvr085915en.html.

${ }^{51}$ For detailed information on the challenges, see The InTERnAtional Rule of LAW: Rise or Decline? (Heike Krieger, Georg Nolte \& Andreas Zimmermann eds., 2019).

${ }^{52}$ On this function of the ECtHR as a functioning constitutional court ("shadow constitutional court") guaranteeing a "consistent social model," see Angelika Nussberger, Die Europäische Menschenrechtskonvention - eine Verfassung für Europa?, 74 JURISTENZEITUNG (JZ) 421, 428 (2019). It is part of the peculiarities of the relationship between the EU and the Council of Europe that EU organs in the substantiation of values consult documents of the Council of Europe, such as the Venice Commission, but at the same time prolong the accession of the EU to the ECHR.

${ }^{53}$ ECJ, Case C-414/16, Egenberger v. Evangelisches Werk für Diakonie und Entwicklung e.V., EU:C:2018:257, Judgment of Apr. 17, 2018.

${ }^{54}$ Opinion of Advocate General Evgeni Tanchev at para. 89, Case C-414/16, Egenberger v. Evangelisches Werk für Diakonie und Entwicklung e.V., (Nov. 9, 2017).

${ }^{55} \mathrm{Id}$. at para. 93 .

${ }^{56}$ For more on the meta-norm in this context, see Volker Roeben, Judical Protection as the Meta-Norm in the EU Judical Architecture, 12 Hague J. ON Rule L. 29-62 (2020). 
already be found in the Kadi jurisprudence. ${ }^{57}$ At this point the EU seeks and finds the connection to Global Constitutionalism, striving to justify the legitimation of public authority across states with regard to human rights, democracy and the rule of law. ${ }^{58}$ Particularly at a time of questioning the purpose of European integration and of disintegration, this value constitutionalism could manifest the aspiration on the one hand to symbolize the reality of integration, the ever closer Union (Art. 1 (2) TEU), and on the other hand to legally operationalize it. The "dispute deprived consensus", which should be manifested by this civil religious concept, must, however, always expect this postulated normative consensus to act as a deterrent because it is not backed up by a material consensus in the Member States. ${ }^{59}$ The claim by the Court that the values clause (Art. 2 TEU) constitutes ratified primary law and that consensus therefore exists is not a supporting counterargument as the conflict arises from substantiating the use of highly abstract values. ${ }^{60}$ The normative threads converge along general clauses, capable of being fleshed out, in the European judiciary to intercept these disintegration tendencies. It is therefore possibly not a coincidence that the new President of the Commission furnished the portfolio of a designated Vice-President with the heading Promoting our European way of life. ${ }^{61}$ The observation confirmed that no society leaves value orientation to chance or to individual discretion. ${ }^{62}$ Value constitutionalism in this respect stands for the will of European society which primary law conceived, by linking the validity of values with the evolution of a European society (Art. 2 (2) TEU). ${ }^{63}$ Value constitutionalism must face another point of criticism. The construction of Art. 19 (1) in connection with Art. 2 TEU is not limited to the value of the rule of law - the Court construes the standard in a more abstract way by making reference to Art. 19 TEU as a whole. The article is substantiated by the values clause, embedded in the constitutional framework of EU law. ${ }^{64}$ In new situations, it would be possible though to fall back on other values, such as human dignity,

\footnotetext{
${ }^{57}$ On the roots of a constitutional meta-principle already in the Kadi jurisprudence of the ECJ, see ECJ, Joined Cases C-584, 593, \& 595/10 P, European Commission et al. v. Kadi, ECLI:EU:C:2013:518, Judgment of July 18, 2013 at paras 99-134 [hereinafter Kadi II] (whereby the Grand Chamber, in modifying the strict jurisprudence of the Court, entered into an assessment of other legally protected rights under primary law). Cf. Jean-Jacques Kasel, La cour de justice de l'Union européenne et la PESC - l'affiare Y. A. Kadi, in Liber Amicorum Vassilios SKouris 3347 (2015); Juliane Kokott \& Christoph Sobotta, The Kadi Case: Constitutional Core Values and International Law - Finding the Balance?, in EUROPEAN COURT OF JUSTICE and External Relations Law: Constitutional Challenges 221 (Marise Cremona \& Anne Thies eds., 2014).

${ }^{58}$ Verena Frick, Sakralisierung des Rechts, in PolitiK, ReCHT UND Religion 93, 98 (Andreas Anter \& Verena Frick eds., 2019); Mattias Kumm, Global Constitutionalism and the Rule of Law, in HANDBOOK ON Global ConstituTIONALISM 197 (Anthony F. Lang \& Antje Wiener eds., 2017); Mattias Kumm, Konstitutioneller Staat und konstitutionelle Autorität, in Verabschiedung und Wiederentdeckung des StaAtes im Spannungsfeld der Disziplinen: Supplement 21 der StaAt 245 (Andreas Voßkuhle, Christoph Bumke \& Florian Meinel eds., 2013); Anne Peters, The Merits of Global Constitutionalism, 62 IND. J. GLOBAL LEGAL STUD. 397 (2009).

${ }^{59}$ On the "heart and soul“ call of Jacques Delors at the beginning of the 1990s, see LAURENCE Hogebrink, EUROPE's HEART AND Soul 13 (2015), available at https://www.globethics.net/documents/4289936/17575651/GE_CEC_2_web.pdf; Karl-Heinz Ladeur \& Ino Augsberg, Die Funktion der Menschenwürde im Verfassungsstaat 8 (2008); Josef Isensee, Menschenwürde: die säkulare Gesellschaft auf der Suche nach dem Absoluten, 131 ARCHIV DES ÖFFENTLICHEN RECHTS 173 (2006).

${ }^{60}$ Cf. Möllers \& SCHNEIDER, supra note 43, at 125-127 (referring also to substantive control of the European value community by the ECJ not being justiciable at least in the context of the TEU art. 7 procedure from TEU art. 19 in connection with TFEU Art. 269).

${ }^{61}$ The Commission President, elected in 2019, furnished the portfolio of a designated Vice-President with the heading, Protecting our European way of life, accessible under https://ec.europa.eu/commission/interim_en. Following criticism, the portfolio was changed to Promoting our European way of life and supplemented with the sub-title Protecting our citizens and our values, available at https://ec.europa.eu/info/strategy/priorities-2019-2024/promoting-our-european-way-life_en. This is a priority of the Commission during its term of office 2020-2024,

${ }^{62}$ Niklas Luhmann, Grundwerte als Zivilreligion, in SOZIOLOGISCHE AUfKLÄRUNG 3, 293 (1981).

${ }^{63}$ Egils Levits, Die Europäische Union als Wertegemeinschaft, in Europa 4.0? 239, 244 (Thomas Jaeger ed., 2018). The values of society (Sentence 2 ) and the value of the state (Sentence 1) are closely knitted together, the first of which can radiate onto the public sector and produce effects there.

${ }^{64}$ Poland, C-619/18 at para. 47.
} 
equality, freedom or democracy, which could be linked to other organizational norms without primary law having criteria as to what concrete form values have got and the priority in which they stand in relation to one another. The set of values in Art. 2 TEU covers nearly all of the activities of the Member States and the Union and permits relevant substantiation by way of the Charter of Fundamental Rights. Transforming the values into fundamental rights in turn represents a subjectification, which mobilizes the EU citizens to defend these values before courts, the consequences of which cannot yet be foreseen for the federal distribution of power between Member States and the EU. ${ }^{65}$ The value constitutional approach of the Court evokes clarity, although clarity (still) is not present in many constellations. The Court itself had decided in the, then renowned, case of Omega, which dealt with the prohibition of killing games, that human dignity in Germany and in the United Kingdom can be interpreted differently. Thus, whilst the game concept was in compliance with EU law, the German authority could forbid the practical implementation thereof by reason of a breach of public order and therewith limit the fundamental freedoms. ${ }^{66}$ The judgment represents the plurality of European values, although it cannot be taken for granted whether the Court would render the same decision today following the entry into force of the human dignity guarantee (Art. 1 CFREU) ${ }^{67}$

The abstractness of values in itself is the price which the heterogeneous "Mega Union" 68 has to pay to integrate this concept and operate with values. This is reflected in the expansion of the Union, in which the Union permitted states to join which did not fulfil the values-still an accession criterion (Art. 49 TEU) - as a means of stabilization but which did not go unnoticed and for which the Commission was duly criticized. ${ }^{69}$ The aforementioned Art. 17 (1) TFEU provides a third example, whereby the wording expressly notes value pluralism beyond the abstractly held freedom of religion, with an explicit reference to Member State particularity. Thus, it is no coincidence that the Commission and the Court are developing value constitutionalism upon the rule of law. It is the value with the highest level of substantiation, supported by extensive preparatory works in the context of the Council of Europe and the European Union itself. ${ }^{70}$ The right to an effective remedy and to a fair trial (Art. 47 CFREU) is a sufficiently concrete fundamental right

\footnotetext{
${ }^{65}$ Armin v. Bogdandy, Tyrannei der Werte? Herausforderungen und Grundlagen einer europäischen Dogmatik systemischer Defizite, 79 ZEITSCHRIFT FÜR AUSLÄNDISCHES ÖFFENTLICHES RECHT UND VÖLKERRECHT (ZAÖRV) 503, 537 (2019) (pointing out that this dogmatic figure has echoes of the Maastricht decision, which rendered the democracy principle justiciable by way of Art. 38 (1) German Constitution); Armin v. Bogdandy \& Luke Dimitrios Spieker, Countering the Judicial Silencing of Critics: Article 2 TEU Values, Reverse Solange, and the Responsibilities of National Judges, 15 EUR. CONST. L. REV. 391, 421 (2019) ("The courts in the EU can apply Article 2 TEU in combination with specific provisions of EU law. Fundamental rights are thereby extended beyond the confines of Article 51 (1) CFR. Such application might bring about a massive power shift to the Union and uproot the balance established by the Treaties between the Union and its member states to the detriment of national autonomy, identity, and diversity.").

${ }^{66}$ ECJ, Case C- 36/02, Omega Spielhallen-und Automatenaufstellungs-GmbH v. Oberbürgermeisterin der Bundesstadt Bonn, ECLI:EU:C:2004:614, Judgement of Oct 14, 2014. See Mielle K. Bultermann \& R. Kranenborg, What if Rules on Free Movement and Human Rights Collide?: About Laser Games and Human Dignity, 31 EuR.L. Rev. 93,93 (2006).

${ }^{67}$ The ECJ has most recently_-so it seems—-followed the dignity-related arguments of the German Constitutional Court and, in the case of Haqbin, declared the complete suspension of social security payments to an asylum seeker due to misconduct to be incompatible with EU law, ECJ, Case C-233/18, Haqbin v. Federaal Agentschap voor de opvang van asielzoekers, ECLI:EU:C:2019:956, Judgement of Nov. 12, 2018 at para. 46 (relating to Art. 20 (4) and 5 Directive 2013/33). See ECJ, Case C-163/17, Jawo v. Bundesrepublik Deutschland, EU:C:2019:218, Judgement of Mar. 19, 2019 at para. 92. According to Koen Lenaerts, Die Werte der Europäischen Union in der Rechtsprechung des Gerichtshofs der Europäischen Union: eine Annäherung 44 EUROPÄISCHE GRUNDRECHTE-ZEITSCHRIFT (EUGRZ) 639, 640 (2017), respecting human dignity is a mandatory EU law standard, which must be complied with.

${ }^{68}$ Thomas Oppermann, Von der Gründungsgemeinschaft zur Mega-Union - Eine europäische Erfolgsgeschichte?, DEUTSCHES VERWALTUNGSBLATT 329-336 (2007).

${ }^{69}$ Ronald Janse, Is the European Commission a Credible Guardian of the Values?: A Revisionist Account of the Copenhagen Political Criteria During the Big Bang Enlargement, 17 InT'L J. Const. L. 43 (2019).

${ }^{70} \mathrm{Cf}$. Meinhard Hilf \& Frank Schorkopf, Art. 2 EUV in DAs ReCHT DER EuropÄISCHEN Union, para. 22-23 (Eberhard Grabitz, Meinhard Hilf \& Martin Nettesheim eds., 60th ed. 2020).
} 
and nevertheless, this guarantee itself is lacking in clarity. ${ }^{71}$ The decisive question is whether EU law values entail not only a rhetorical commitment but in fact a consensual value of national identities manifested in fundamental constitutional structures. ${ }^{72}$ The ECJ should resist the temptation to substantiate EU values in its jurisprudence widely and comprehensively imperative in order to render them subsumable. It is an open question whether the Court already has sufficient legitimate recourses and the sensitivity has to have the last word on the concrete form of common European values - or not. More important still is the recognition that the substantiation and procurement of values is a social responsibility among and within the Member States. It requires an appropriate form, which facilitates societal understanding. As a result, the dialogue of the highest courts ${ }^{73} \mathrm{can}$ at most have a supporting role, the European Court of Justice presumably would not be able to achieve the substantiation and the creation of a hierarchy pertaining to multipolar clashes of values with the necessary acceptance. With the conflicting interpretations in mind, the weight is again shifting towards the federal constitutional point of view on integration. The cooperation in the club of Member States is receding into the background. The political union is federalizing itself into a value constitutional union. ${ }^{74}$

The Constitutional Treaty failed in its time also because of the openly represented transformation of the Union, away from a delegation model towards a European federation. The result of the early years of European integration remains: the Member States agree to cooperate in a treaty established political union. For the time being, they do not have a consensus on a "good order" for Europe.

\footnotetext{
${ }^{71} \mathrm{Cf}$. Christoph Möllers, Reflexionen über den Rechtsstaat, 53 ZEITSCHRIFT FÜR RECHTSPOLTIK 27 (2020).

${ }^{72}$ On this point, see Andreas Voßkuhle, The Idea of the European Community of Values 38 (2018) (concluding that referring to the protection of national identity is ruled out when the measures of individual states contradict the narrowly interpreted basic values of the EU).

${ }^{73}$ Francesco Perrone, The Judicial Path to European Constitutionalism: The Role of the National Judge in the Multi-Level Dialogue, in Liber Amicorum Vincent De Gaetano 395 (2019); Koen Lenaerts, Upholding the Rule of Law through Judicial Dialogue, 38 YeArbook Eur. L. 1, 6 (2019).

${ }^{74} \mathrm{Cf}$. Nettesheim, supra note 10, at 103 (criticizing the Union's recent attempt to describe itself as a "legal community" (Rechtsgemeinschaft), connected to the cooperation model, to transform to the rule of law or to "jurisdiction"). See also Armin v. Bogdandy, Jenseits der Rechtsgemeinschaft. Begriffsarbeit in der europäischen Sinn- und Rechtsstaatlichkeitskrise, 52 EUROPARECHT 487 (2017).
}

Cite this article: Schorkopf F (2020). Value Constitutionalism in the European Union. German Law Journal 21, 956-967. https://doi.org/10.1017/glj.2020.51 